\title{
Analysis on the Social Culture in the Art Theme of China Gongyi Grotto Temple
}

\author{
Xiaohui Zhang \\ Huanghe Science and Technology College \\ Zhengzhou, China 450046
}

\begin{abstract}
As the three-dimensional image carrier of Buddhist art in the Northern Wei Dynasty, the stone carvings in Gongyi Grotto Temple has a all-inclusive content and form, with its performance theme including the magnificent Buddha, Buddha Figure of Buddha and the royal family jointly sharing pleasure, secularized civilian inscriptions, as well as men and women and the Buddhist monks with belief of Buddha in the late. Its transformation of theme and content from magnificent complex to simple common customs and from the grim majesty to intimate civilians, shows the change of the society and the change of dominant ideology, from which we can look into a variety of vicissitude from the early Northern Wei Dynasty to the Tang Dynasty.
\end{abstract}

Keywords-Gongyi Grotto Temple; expressive theme; Buddha statues; Buddhism and Confucianism

\section{INTRODUCTION}

The form of Grotto Temple originated from India, and initially the caves were excavated among the natural rocks and cliffs and used as the places for monks' practice activities. From the architectural form, some caves are used for residence and some for worship. After introduced into China, this form of Grotto Temple has not met more and more Buddhist followers' demands for pilgrimage along with the increasing secularization of Buddhism, so the grotto temple in China began to excavate shallow niche or directly chisel statues on the natural cliff. Gongyi Grotto Temple of Henan becomes an important example in this course after grotto temple was introduced to China.

Gongyi Grotto Temple was built in the Taihe period of the reign of Emperor Xiao Wen in the Northern Wei Dynasty, and a number of caves and statues were chiseled in the Jingming period of the reign of Emperor Xuanwu. Now there exist main hall, eastern and western meditation halls and monastic gate that were rebuilt in the reign of Tongzhi in the Qing Dynasty. Behind the temple is a $120 \mathrm{~m}$ long grotto group, including five stone caves by the cliff, three Cliffside Giant Buddha statues and one thousand-Buddha niche, and additionally there are 328 Cliffside statue niches, three giant Cliffside statue, one thousand-Buddha niche, 255 small statue niches, 328 Cliffside statues niches, totaling 7743 statues and 186 inscriptions, which have been built since the Northern Wei Dynasty and form a relatively concentrated grotto group from west to west.

\section{THE EXPRESSION OF DIFFERENT THEMES FOR GROTTO TEMPLE ART}

Art comes from life, and as the three-dimensional image carrier of Buddhist art in the Northern Wei Dynasty, the stone carvings in Gongyi Grotto Temple has an allinclusive content and form, with its expressive content including both the god and the human, both the noble and the labourers. With the artistic technique of circle carvings and line engraving and the copper, stone or clay statues, it is small and exquisite, wonderful and unique, compared with grand and magnificent grotto art in the Tang Dynasty. As the beginning of grotto expression for carving art, it has unique artistic value.

Grotto art is Buddhist art, and its form of sculpture shows Buddhist thought and its occurrence and development process. Gongyi Grotto describes various stories and images of Buddha, Lohan, Bodhisattva, Foubenxing and Foubensheng in virtue of the specific life and quality and facial features of human, with its theme and content closely related to the life of people. It comes from people's desire for better future life and accumulates the secular artistic expression of grotto art.

According to the change of times, the theme of Gongyi Grotto possibly has two processes of Buddha figure and folk diagram. When the royal family in the Northern Wei Dynasty rose, the grotto entered its early construction stage and became the exclusive place of the royal family and the noble for worshipping Buddha and praying, so the themes most are Buddha figures to carry forward factional moral and the statues most are the rulers of all circles, such as God, Buddha and the emperor. Large and grand and magnificent empress figures become the theme but the civilian statue and inscription is few. With the decline of the Northern Wei regime, Gongyi grotto temple has more and more pilgrims for praying, gradually expanding to the common folks, so there appear many steles of common folks for making a wish. And then the theme transfers from god and Buddha into the ancestors and celebrities on the earth, and the expressive meaning is direct and visual, both the themes and the contents secularized.

\section{A. Grand and Magnificent Buddha Statues}

Gongyi Grotto Temple faces south, and its Buddha statues with enlightenment function are mainly distributed in 
the five caves from west to east. There are 3 giant Cliffside statues, and 15 existing most representative empress figure relievos. Buddha statues and figures is the representative of main grotto theme in the early period.

The 5 caves have a little difference in their interior shape, and they all have the central column with Buddha statures carvings around. They are grand and magnificent. Among them, the first cave has the largest capacity and is most intact, with most artistic attainments.

The first cave is formed in the period of Emperor Xiaowen in the Northern Wei Dynasty, where comely and gilled Buddha statues and concise texture process show the unique artistic characteristics in the early period of Northern Wei Dynasty, and it tries to present the dignity and authority of Buddha statues and show the supreme of divine right. The first cave is square, and is the largest among the five caves. It is about 65 meters long and about 6 meters high, and the big niches on the all sides of its central column become the visual center of the whole cave. In the niches, there is one Buddha, two Bodhisattvas and two disciples, with flame pattern bas-relief behind the Buddha on the seat body, as well as symmetrical flying apsaras, metaplasia and Lotus, and there engraved lions with long hairs crouching on the right and left sides of Buddha seat. The main statue on the south side of central column has a long and round face, a slightly square forehead, clear and prominent facial features, proportionate body, with a impavidity stamp on the right hand and a wish giving stamp on the left hand, and with lowcollar and broad-webbing cassock drooping in the front of the seat, decorated with complicated and ornate patterns on the cassock. The Buddha seating in the east has a square face, plump cheeks, slightly closing and smiling eyes, with fluent and natural bodhisattva wear, especially the silk fabrics flying behind the back of the head and the chaplet with scrolled grass pattern on the neck, to highlight the trend of relief from secularism.

The second cave was completed in the second year of the Tang Dynasty, and its statues have plump face and slight chubby body, different from the comely and gilled sculpture in the Northern Wei Dynasty. The cave has a small capacity, is $5 \mathrm{~m}$ long from south to north and about $6 \mathrm{~m}$ wide from east to west, $3.6 \mathrm{~m}$ high. On the southern side of its central column, 3 Buddha niches are chiseled from top to bottom, and in the niches there are one Buddha, two Bodhisattvas, two disciples and two Hercules, who all stand on a lotus flower or lotus seedpod.

The third cave has its representative carving that is the five sitting Buddha statues in the niches on the southern side of the central column. The main stature in the south has a little square face, with head leaning forward and rosy lips slightly opening, like chanting sutra or preaching and disabusing for all living beings. Its modest and dignified manner symbolizes the infinite authority, showing the powerful might of thearchy and the insignificance of ordinary folks. On both sides of the niche top margin, flying apsaras rilievos are carved with delicate and exquisite dress textures, significantly different from the solemn and concise texture in the early period of Northern Wei Dynasty, which shows the secularization style of god apt to people.

\section{B. Buddha Figure to Highlight the Theocracy}

The second key representative theme and content is the "Empress Figure", and currently Gongyi Grotto Temple has 15 figures, which is the most intact stone carving art preserved among existing grottos in China, praised as "a unique in China" by the Buddhist circle. Especially the Buddha figure in the first and fourth caves is wonderful, vivid and lifelike, and so description is never exaggerated.

On both sides of the gate of the first cave, three layers of Buddha figures are engraved, among which on the east is the line of male contributors with the emperor as head, and on the west is the line of female contributors with queen as head separately led by monks and nuns. Especially the 15 lines of thousand-Buddha figures on all the walls of the central column, have the Buddha in dress of more than 10 styles. In addition, the rilievo of dance and singing players are engraved on the base of the square pillar, and the players are lifelike, with guan, piano, drum, flute, Triton, Jiegu and other Buddhist musical instruments in their hand, representing Buddhist music, as if the music remains lingering long in the air. Among these relievos, there are Buddha followers and also nobles in a natural and graceful manner, which is designed to declare to the public that the royal family as the summoner of theocracy on earth has supreme and indubitable rights and status, so as to add strong political overtones and didactic function for the Buddha figure.

Below the west side of the gate of the fourth cave, there is a Buddha figure, in which a honour guard of Buddha with a large retinueis is led by a monk, and the contributors have obese body and stern look, and the dependants are almost one-third smaller than the main statue, and they are in different poses, some lifting skirt by hand or some holding a fan or a umbrella or some holding sacrifice in both hands, flowing the empress in a humble manner to burn incense and worship the gods. Compared with the Buddha Figure in the first cave, the scene moves to the earth from the heaven, more clearly declaring that the royal family has the native honor in the world, and undoubtedly it is a more direct manifesto of imperial power.

\section{The Secular Inscription of Civilians}

With the decline of the Northern Wei regime, Gongyi grotto temple has more and more pilgrims for praying and the civilian followers began to visit it frequently, so there appear many steles of common folks for making a wish and then the theme and content of civilians and the marketplace formed, where people express their wishes such as praying for a son, worshiping ancestor, desiring wealth and peace. But the form of praying is different from the royal and the noble, and maybe due to the limited area of grotto temple or the limited money of civilians or the constraint of religious decree and ordinances, the praying of common people can be expressed only by simple inscription, unable to enjoy the expression form of grand and magnificent statue and vivid figures. This fully proves the hierarchical ideology of feudal society is never insurmountable for the secular people. 
Secular picture is nothing more than the most direct wishes of common people for praying for sons and good fortune.

First, it is to pray for wisdom, for instance, the threebrother statue of Zuo Xuan et al. on April 3 of the second year in the reign of Tianbao of Northern Qi Dynasty (AD 551) is designed to blessing for "wisdom and acumen"; on April 11of the same year, Hui Feng's statue designed for "praying disciples' acumen and knowledge "; and other statues designed for the desire of "having the learning idea, knowing more than people think ". Second, it is to pray for health and longevity, for instance, the statue of monk in giving instructions is designed on April 8 of the second year in the reign of Tianbao of Northern Qi Dynasty (AD 551) to bless for "quick removal of disaster"; the Guo Shiwei's statue in an unknown year designed to wish a speedy dispel of illness from his wife and sister-in-law. Third, it is to worship ancestors by setting up statue of the deceased relatives for releasing souls from purgatory, for instance, in the first year of the reign of Putai of the North Wei Dynasty (AD 531), monk Fa Yun built statues for his deceased parents; Qiu Jinhe built statue for his deceased daughter-inlaw; Wei Xianming built statue for his deceased daughter; and on March 3 of the third year of Tianping period of East Wei Dynasty (AD 536), Yang Dasheng of Bingping of Youzhou built statues for his deceased family including his parents, young brother and sister as well as his wife, to wish them have a rich, healthy, peaceful and happy life in the heaven; on September 5 of the fourth year of Tianping period of East Wei Dynasty (AD 537), Hui Qing built statue for his deceased young brother Zeng Xian, to wish his family dependants are favored by the Buddha and all Buddhist disciples early accomplish their cultivation of doctrine; and on December of 25, Liang Bi of Wude County of Huaizhou built Kwan-yin statue to wish his deceased father have a happy life in heaven.

Before the development in the Tang Dynasty, Gongyi grotto temple had become civilianized, which carried the faith and spiritual solace of the common people. Various statues and inscriptions emerged, and sporadic female statues also appeared, such as the statue of Gong County head's wife in the third year of Tianping period of the East Wei Dynasty (AD 536) and the statue of female Buddhist disciple $\mathrm{Li} \mathrm{Nu}$ in the second year of Tianbo period of the Northern Qi Dynasty (AD 551). In the Tang Dynasty, figures were more diversified and the quantity of statues and inscriptions increased significantly. There is not only local people but also 'Liu Diansheng from Zhang Dao' family of Chang'an County" and others; there is not only blessing for themselves but also the blessing of monks for the peace of people in the world and the safety of kingdom and benefactors; there is not only male behavior but also many female statues. The Buddha believing and worshiping conditions of the people in the Tang Dynasty and the change of social conduct can be found here.

From the grand and magnificent Buddha statue to the Buddha figure of god and royal family till to the civilianized inscriptions and the later Buddha believing men and women and the temple monks, we can find the change of theme and contents from magnificence and complexity to simpleness and secularization, from marblehearted and dignified majesty to genial civilians, which fully shows the change of the society and the mainstream ideology, so that we can know the various change from the early Northern Wei Dynasty to the Tang Dynasty.

\section{CONFUCIANISM IN THE ARCHITECTURE OF STONE Cave Temple}

In more than two thousand years after Emperor $\mathrm{Wu}$ in Western Han Dynasty "rejecting the other schools of thought and respecting only Confucianism", the ideology of Confucianism that had been occupying the dominant position all the time had enormous influences on all aspects of ancient Chinese society. It is the main spirit of thousands of years of Chinese culture. Although being introduced and prospered after Han dynasty, Taoism and Buddhism were in subordinate position. Confucianism has been the orthodox thought in people's heart all the time.

In early times, Confucianism is well arranged thinking pattern with "fitting between square and circle ducts" and trinity of "heaven, earth and man". It takes the universe as a unified and well-organized huge system of heaven-earth-man, and then compares human society as a control system with distinctive social status and rigorous management. It is a dynamic and human-centered system that human integrates with heaven and earth. In the process of integration of Confucianism thought and Buddhist culture, it produces the grottoes architectural form that has unique features of Chinese traditional grottos architecture, such as palace, ancestral temple of a ruling house, altar and mausoleum, etc. Confucianism advocates the center and orderliness. In the architectures of Stone Cave Temple in Gongyi, the plane arrangement embodies the square and symmetry and the closed type of spatial processing, "all without exception show the harmonious relationships between human and nature, and correspond to aesthetic ideal of the theory that man is an integral part of nature in Chinese traditional aesthetics". The symmetric structures also powerfully show the rigid hierarchy in the world of Buddhism. The rigid obsession of hierarchy in Buddhism combines with the obsession of hierarchy in Chinese traditional design, ethics and sets of etiquette such as the monarch and his subjects, father and son, husband and wife and the older and the younger. The axisymmetric forms of layout in architectural groups in the temple also show this. Looking from the structures of the roof of the grotto and portrayals in the surrounding walls, patterns such as lotus, Flying Apsaras, vertical mantles that symbolize the solemnity of the land of Buddha are painted. Most of them carry out the spatial partition by using skill and music in heavenly palace, and Flying Apsaras. Thousand Buddha are painted on the wall with distinctive hierarchy. The Confucianism advocates the order of superiority and inferiority, so there are strict regulations in the architectures of Stone Cave Temple such as the standard width of a room in an old-style house, shape and structure and decoration. It is forbidden to breach and arrogate the system. 
Buddhism tourism is a large mainstream in religious travel and has got considerable development in recent years. People also pay more and more attention on the Stone Cave Temple in Gongyi. Further improving the tourism of Stone Cave Temple also can better promote people to show their concerns over the architectural arts and further promote the development level of modern architecture. The author thinks that Gongyi people should take measure such as the union of the scenic region and local areas, develop characteristic tourist commodities, perfect the tourist functions of the city, highlight the uniqueness and cultivate professional tour guides for the scenic spot of Buddhism to ensure the sustainable development of Buddhism cultural tourism resources in Gongyi.

\section{CONCLUSION}

The sculptures on ancient architectures more or less are marked with the marks of culture, religion, ideas and folk customs in different times. Architecture heritages are important signs of human civilization. Carving skill is the historical creation of human beings. It is one-off and nonrenewable. Meanwhile, it is the important mission endowed by the era for us to respect, protect and continue traditional cultural skills and carry forward its artistic application. As an important part of ancient Buddhist architectures in our country, the Stone Cave Temple in Gongyi uses its unique ideological content and culture to attract numerous scholars for further research. The author hopes to use this article as the opportunity to further promote people's concerns for ancient architectures and make more and more researchers find the source and soul of creation in ancient architectures.

\section{REFERENCES}

[1] Zhuang Yuguang, Hu Shi. Architectural Ornament in Ancient China • Sculpture [M], Jiangsu Fine Arts Publishing House in Nanjing, in 2007

[2] Ma Shichang, Ding Mingyi. Introduction to Archaeology of Chinese Buddhist Grottoes [M], Beijing: Cultural Relics Press, 2007

[3] Tang Yongtong. Buddhism History of Han, Wei, Jin, Southern and Northern Dynasties [M], Shanghai: Shanghai Bookstore Publishing House, 1991

[4] Cultural Relics Work Team in Bureau of Culture in Henan Province, Gongxian Cave Temple [M], Beijing: Cultural Relics Publishing House, 1963

[5] Jing Sanlin. Art History of Chinese Grottoes Sculpture [M], Beijing: People's Fine Arts Publishing House, 1988:149

[6] Zhang Weiqing, Gao Yiqing. The History of Chinese CultureVolume Four [M], Shandong: Shandong People's Publishing House, Ed.1, Feb. 2002 